\title{
Pemanfaatan Ruang Akuakultur Potensial melalui Diseminasi Teknologi Budidaya Metode Vertikal untuk Meningkatkan Kapasitas Pembudidaya dan Produksi Rumput Laut di Pesisir Desa Ujung Baji Kabupaten Takalar
}

\author{
Nursidi $^{1}$, Heriansah ${ }^{2}$, Fathuddin ${ }^{2}$, Nur Fajriani Nursida ${ }^{2}$ \\ ${ }^{1}$ Politeknik Pertanian Negeri Pangkajene dan Kepulauan \\ 2 Institut Teknologi dan Bisnis Maritim Balik Diwa Makassar \\ E-mail: nursidilatif@gmail.com
}

\author{
Article History: \\ Received: March 25 2021 \\ Revised: April 27th 2021 \\ Accepted: May 30th 2021
}

Keywords: seaweed cultivation, vertically method, technology dissemination, utilization of aquaculture space, cultivator capacity

\begin{abstract}
Gracillaria changii is a high-value seaweed cultivated by the community on the seashore of Ujung Baji Village in Takalar Regency. This cultivation has become the local community's primary source of income, yet production and productivity are still inadequate. To address the issue, this technology dissemination aims to give cultivators with information and abilities in using the vertical method of cultivation to boost production and productivity aquaculture of $G$. changii. This dissemination used the Community Development (CD) method, which involved the community in every action, including planning, designing and assembling technology, implementation, and assessment. This dissemination was successful in increasing the Hati Mulia Cultivator Group's knowledge and capabilities in vertical seaweed cultivation. When compared to horizontal cultivation, this vertical cultivation technology can increase G. changii production and productivity by at least two to three times.
\end{abstract}

\section{Pendahuluan}

Desa Ujung Baji merupakan salah satu desa di Kecamatan Sanrobone Kabupaten Takalar Provinsi Sulawesi Selatan yang memiliki potensi pengembangan budidaya rumput laut. Desa pesisir ini berbatasan langsung dengan Selat Makassar dengan luas wilayah 3,31 $\mathrm{km}^{2}$, ketinggian $14 \mathrm{~m}$ di atas permukaan laut (DPL), dan jumlah penduduk 2.561 jiwa ${ }^{1}$ yang umumnya bermata pencaharian sebagai pembudidaya rumput laut dan sekaligus sebagai nelayan. Berdasarkan pengamatan morfologi dan analisis DNA molekuler, rumput laut yang dibudidayakan di laut dan di tambak oleh sebagian besar

1 BPS, Kecamatan Sanrobone Dalam Angka 2020 (Takalar, 2020), https://takalarkab.bps.go.id/ publication/2020/09/28/b6fe3fe83c14387edfce3a34/kecamatan-sanrobone-dalam-angka-2020.html. 
masyarakat di Desa Ujung Baji adalah spesies Gracillaria changii ${ }^{2}$. Rumput laut yang tergolong alga merah ${ }^{3}$ ini toleran terhadap perubahan lingkungan dan merupakan sumber agar-agar pada industri makanan ${ }^{4}$, dapat menjadi antioksidan dan mengurangi resiko penyakit kardiovaskular sehingga berpotensi sebagai bahan pangan fungsional ${ }^{5}$. Komposisi kimia $G$. changii bergizi tinggi dengan kandungan serat $64,74 \%$, lemak hanya $0,30 \%$, total asam amino $91,90 \%$ dengan asam amino esensial 55,87\% ${ }^{6}$.

G. changii yang dikenal dengan nama lokal sango-sango laut atau jombe dibudidayakan oleh masyarakat Desa Ujung Baji di sepanjang pesisir. Perairan pesisir Ujung Baji memiliki keunikan berupa perairan yang memiliki spora yang dapat membuat bibit Gracillaria sp. tumbuh sangat subur7. Perkembangan budidaya rumput laut di Desa Ujung Baji tidak lepas dari peran masyarakat yang berpartisipasi aktif dalam mengembangkan usahanya. Peningkatan kegiatan ekonomi ini dapat dilihat dari pengembangan usaha mikro yang dikelola oleh masyarakat, baik secara individu maupun secara bersama-sama. Gambar 1 menunjukkan budidaya G. changii yang dilakukan oleh masyarakat di pesisir Desa Ujung Baji.
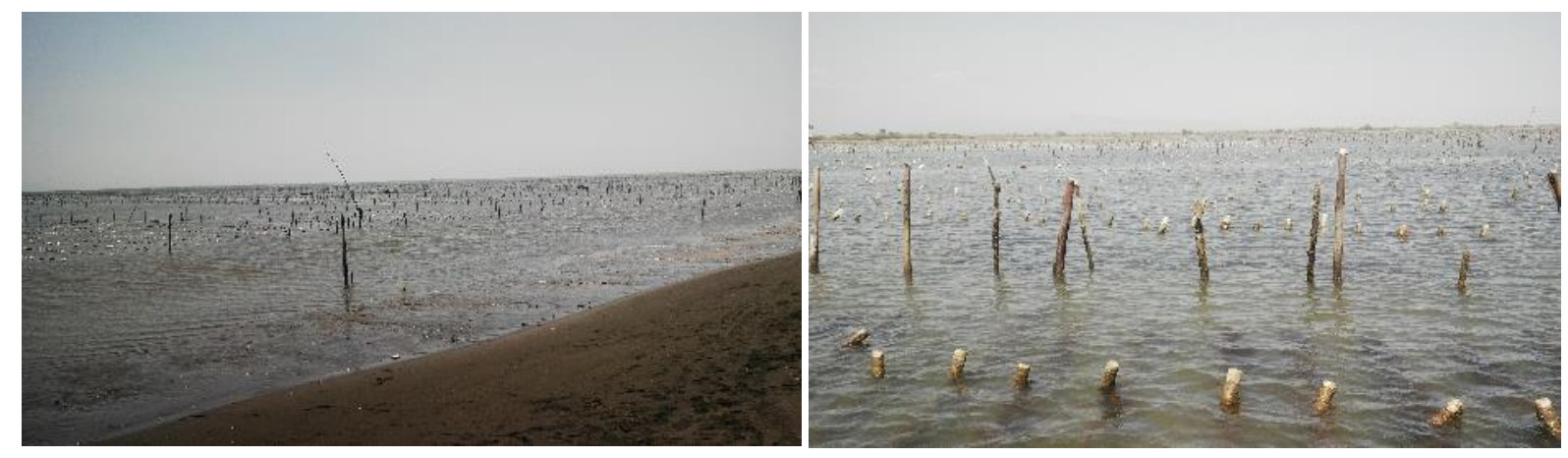

Gambar 1. Budidaya G. changii di Pesisir Desa Ujung Baji Kabupaten Takalar

Komunitas dampingan pada kegiatan diseminasi teknologi ini adalah masyarakat

2 N. I.S. Arbit et al., "Morphological and Genetic Analysis of Gracilaria Sp. Cultured in Ponds and Coastal Waters," IOP Conference Series: Earth and Environmental Science 370, no. 1 (2019).

${ }^{3}$ Wei Kang Lee, Yi Yi Lim, and Chai Ling Ho, "PH Affects Growth, Physiology and Agar Properties of Agarophyte Gracilaria Changii (Rhodophyta) under Low Light Intensity from Morib, Malaysia," Regional Studies in Marine Science 30 (2019): 100738, https://doi.org/10.1016/j.rsma.2019.100738.

${ }^{4}$ Lin Wei Jong et al., "Micropropagation and Protein Profile Analysis by SDS-PAGE of Gracilaria Changii (Rhodophyta, Solieriaceae)," Aquaculture Reports $1 \quad$ (2015): 10-14, http://dx.doi.org/10.1016/j.aqrep.2015.03.002.

5 Pei Teng Chan et al., "Antioxidant and Hypolipidaemic Properties of Red Seaweed, Gracilaria Changii," Journal of Applied Phycology 26, no. 2 (2014): 987-997.

${ }^{6}$ Pei Teng Chan and Patricia Matanjun, "Chemical Composition and Physicochemical Properties of Tropical Red Seaweed, Gracilaria Changii," Food Chemistry 221 (2017): 302-310, http://dx.doi.org/10.1016/j.foodchem.2016.10.066.

7 "Indonesia Lupakan Keajaiban Di Takalar Halaman All - Kompasiana," https://www.kompasiana.com/harrystbagindo/5b73f105c112fe45b70d2ce5/indonesia-lupakankeajaiban-di-takalar?page=all. 
pembudidaya rumput laut yang tergabung dalam Kelompok Perikanan Hati Mulia dengan jumlah anggota 11 pembudidaya. Anggota kelompok pembudidaya ini telah melakukan kegiatan budidaya rumput laut antara 5-10 tahun. Jumlah bentangan yang dimiliki oleh setiap anggota bervariasi antara 50-80 bentang dengan panjang bentangan 25 meter dan jarak tiap bentang $50 \mathrm{~cm}$. Berat bibit yang ditanam pada setiap titik ikat sekitar 50 gram dengan jarak sekitar $30 \mathrm{~cm}$. Jika dihitung secara matematis, maka berat bibit yang ditanam oleh pembudidaya dalam 1 siklus sekitar 200-300 kg. Produksi yang dihasilkan menurut Ketua Kelompok antara 1-2 ton (basah) per siklus (40-45 hari). Jika dirataratakan harga $G$. changii Rp8.000,00 per kg, maka jumlah pendapatan kotor yang diperoleh pembudidaya sebesar Rp4.000.000,00-Rp8.000.000,00 per siklus. Usaha budidaya ini telah memberikan pilihan usaha baru bagi pembudidaya rumput laut, terutama yang tidak mempunyai tambak. Namun demikian masih mendapatkan kendala sehingga hasil yang diperoleh belum optimal ${ }^{8}$.

Masalah yang dihadapi pembudidaya rumput laut adalah rendahnya produksi yang disebabkan oleh tidak termanfaatkannya sebagian besar nutrient yang ada di kolom air'. Metode budidaya yang diterapkan oleh masyarakat di Desa Ujung Baji adalah metode longline horisontal. Metode horisontal hanya memanfaatkan bagian permukaan perairan saja sehingga membutuhkan perairan yang luas, biaya yang relatif tinggi, perawatan yang sulit, rentan terhadap berbagai perubahan lingkungan, serta dapat berpotensi memicu konflik pemanfaatan ruang10,11,12. Secara ekologis rumput laut masih dapat tumbuh pada kolom perairan yang masih mendapatkan penetrasi cahaya matahari untuk fotosintesis ${ }^{13}$ sehingga kandungan nutrien perairan masih memungkinkan tersedia di kolom perairan ${ }^{14}$.

Mengacu pada metode budidaya yang diterapkan oleh masyarakat Desa Ujung Baji, khususnya pembudidaya yang menjadi komunitas dampingan, maka perlu dilakukan diseminasi teknologi budidaya metode longline vertikal untuk meningkatkan produktivitas lahan. Metode ini dikenal pula dengan istilah vertikultur dimana rumput

${ }^{8}$ Mugi Mulyono et al.., "Performa Budidaya Rumput Laut" 15, no. 2 (2020): 71-77.

9 Nursidi, Mauli, and Heriansah, "Development of Seaweed Kappaphycus Alvarezii Cultivation through Vertical Method in the Water of Small Islands in South Sulawesi, Indonesia," AACL Bioflux 10, no. 6 (2017): 1428-1435.

10 Ibid.

11 Muhammad Hendri, Rozirwan Rozirwan, and Rezi Apri, "Optimization of Cultivated Seaweed Land Gracilaria Sp Using Vertikultur System," International Journal of Marine Science 7, no. 43 (2017): 411422.

12 Petrus Rani Pong-Masak and Nelly Hidayanti Sarira, "Effect of Depth on the Growth and Carrageenan Content of Seaweed Kappaphycus Alvarezii Cultivated Using Verticulture Method," E3S Web of Conferences 147 (2020).

13 Ibid.

14 Lestari Lakhsmi Widowati et al., "Efisensi Produksi Rumput Laut E. Cotonii Dengan Metode Budidaya Longline Vertikan Sebagai Alternatif Pemanfaatan Kolom Air," Indonesian Journal of Fisheries Science and Technology (IJFST) 11, no. 1 (2015): 47-56. 
laut ditanam secara vertikal sampai pada kedalaman penetrasi cahaya matahari ${ }^{15}$. Dengan demikian penanaman rumput laut tidak hanya pada satu baris saja, tetapi beberapa baris pada kolom yang sama ${ }^{16}$. Metode budidaya ini dapat meningkatkan produksi dan produktivitas lahan dua tiga kali lipat tergantung jumlah kolom yang digunakan. Jika produksi $G$. changii dengan metode longline horisontal 1-2 ton basah per siklus, maka produksi pembudidaya dengan menggunakan metode vertikal dapat meningkat dua atau tiga kali lipat tergantung dari jumlah kolom yang digunakan.

Berlandaskan analisis situasi komunitas dampingan serta keunggulan metode vertikal pada budidaya rumput laut, maka kegiatan diseminasi teknologi perlu dilakukan. Diseminasi ini bertujuan untuk memberikan pengetahuan non-teknis dan keterampilan teknis kepada pembudidaya rumput laut G. changii dalam menerapkan teknologi budidaya metode vertikal. Teknologi ini pada prinsipnya memanfaatkan ruang akuakultur potensial sehingga diharapkan dapat bermanfaat secara nyata dalam meningkatkan produksi dan produktivitas lahan budidaya secara berkelanjutan. Diseminasi teknologi ini diharapkan pula dapat menjadi pengungkit pengembangan usaha rumput laut masyarakat sekitar.

\section{Metode}

Kegiatan diseminasi teknologi budidaya rumput laut metode vertikal kepada pembudidaya rumput laut Kelompok Hati Mulia (komunitas dampingan) dilaksanakan di Desa Ujung Baji Kecamatan Sanrobone Kabupaten Takalar Provinsi Sulawesi Selatan (Titik Koordinat: 5²7'13.1"S 119²3'28.7"E) (Gambar 2)
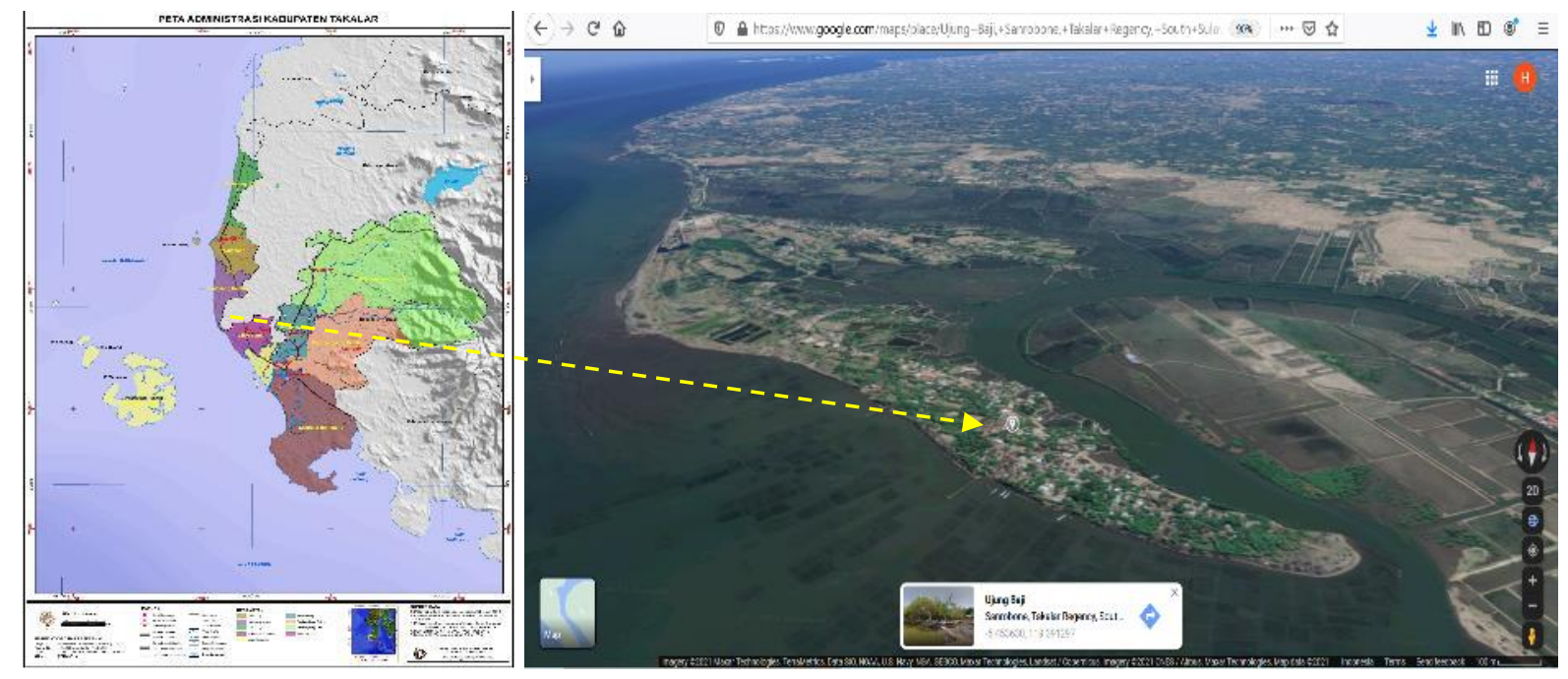

\footnotetext{
15 Ibid.

16 Ibid.
} 
Gambar 2. Peta Kabupaten Takalar ${ }^{17}$ dan Map Desa Ujung Baji Kecamatan Sanrobone ${ }^{18}$

Ketepatan pemilihan metode pengembangan akan menghasilkan program yang efektif dan efisien yang dapat diaplikasikan dan memberi manfaat bagi masyarakat ${ }^{19}$. Oleh karena itu, metode yang tepat digunakan pada diseminasi teknologi ini adalah metode Community Development (CD). Community development merupakan pengembangan masyarakat untuk mencapai transformasi sosial-budaya, politik, ekonomi, dan teknologi yang berbasis masyarakat sebagai subyek program, berbasis potensi sumberdaya yang ada, dan berbasis keberlanjutan untuk pengembangan kapasitas dan kesejahteraan masyarakat ${ }^{20}$. Partisipasi komunitas dampingan diwujudkan dalam keterlibatan aktif dan langsung pada setiap tahapan kegiatan serta menyediakan lahan percontohan dan tempat pelatihan. Tahapan kegiatan diseminasi mengikuti alur berikut ini:

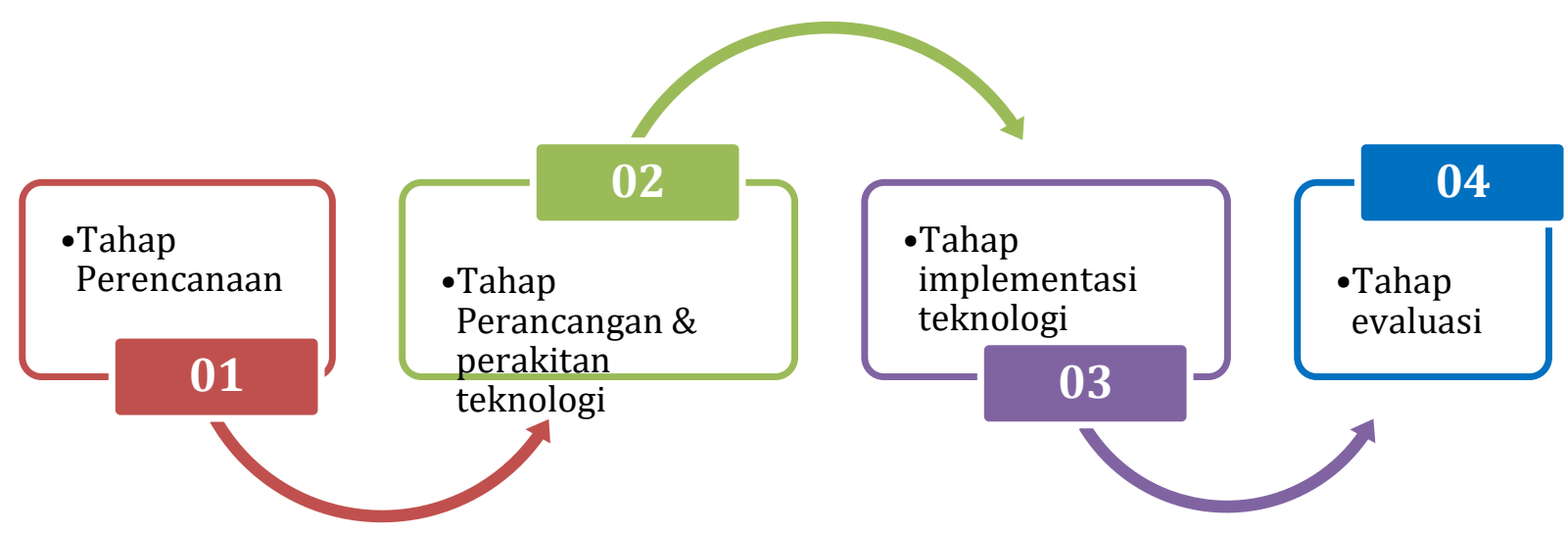

Gambar 3. Alur Pelaksanaan Diseminasi

Pelaksanaan diseminasi dilakukan melalui tiga model, yaitu: (a) penyuluhan nonteknis, (b) pendampingan teknis, dan (c) demonstrasi plot. Penyuluhan non-teknis dilakukan melalui penyampaian pengetahuan teoritis tentang teknologi budidaya rumput laut metode vertikal. Pendampingan teknis dilakukan melalui penyampaian keterampilan teknis membuat konstruksi budidaya rumput metode vertikal. Demonstrasi plot dilakukan melalui kegiatan praktek langsung di lahan percontohan, mulai dari pengikatan bibit, pemasangan konstruksi, dan pengontrolan pada saat

17 “Administrasi-Takalar1,” https://petatematikindo.files.wordpress.com/2013/01/administrasitakalar1.jpg.

18 "Ujung Baji - Google Maps," https://www.google.com/maps/place/Ujung+Baji,+Sanrobone,+Takalar+Regency,+South+Sulawesi/.

19 Chabib Musthofa and Muhammad Andik Izzuddin, "Pengembangan Model Usaha Tanaman Hidroponik Melalui Pemanfaatan Teknologi Tepat Guna Berbasis Media Informasi Pada Komunitas UMKM Pertanian Perkotaan," Engagement : Jurnal Pengabdian Kepada Masyarakat 3, no. 1 (2019): 92-105.

20 I Wayan Edi Arsawan, Ni Made Kariati, and I Wayan Sukarta, "Pemberdayaan Berbasis Comunnity Development: Studi Ekploratorif Di Kawasan Wisata Sangeh," Sosial dan Humaniora 6, no. 3 (2016): 238-248. 
pemeliharaan rumput laut. Ketiga kegiatan ini dilakukan dengan menekankan keterlibatan komunitas dampingan secara aktif. Untuk kepentingan evaluasi program dilakukan pre-test dan post-test pengetahuan dan keterampilan komunitas dampingan serta perbandingan produksi yang dihasilkan.

\section{Hasil Pendampingan}

\section{Tahap Perencanaan}

Tahap perencanaan diseminasi diawali melalui survei dengan mengobservasi kondisi eksisting lokasi serta melakukan wawancara dengan pemerintah desa, masyarakat, dan komunitas dampingan. Survei dilakukan untuk menggali informasi terkait dengan potensi unggulan dan permasalahan serta teknologi yang dibutuhkan untuk mengoptimalkan potensi unggulan yang dimiliki dan mengatasi permasalahan yang dihadapi. Survei ini akhirnya menghasikan analisis situasi dan rencana teknologi yang akan didiseminasikan sebagaimana yang diuraikan pada Pendahuluan. Pada tahap perencanaan ini juga dibahas teknis pelaksanaan diseminasi yang disepakati sebagaimana alur pelaksanaan pada Gambar 3. Dengan demikian, sejak awal komunitas dampingan telah diajak untuk berpatisipasi aktif dalam diseminasi ini. Dokumentasi kegiatan pada tahap perencanaan disajikan pada Gambar 4.
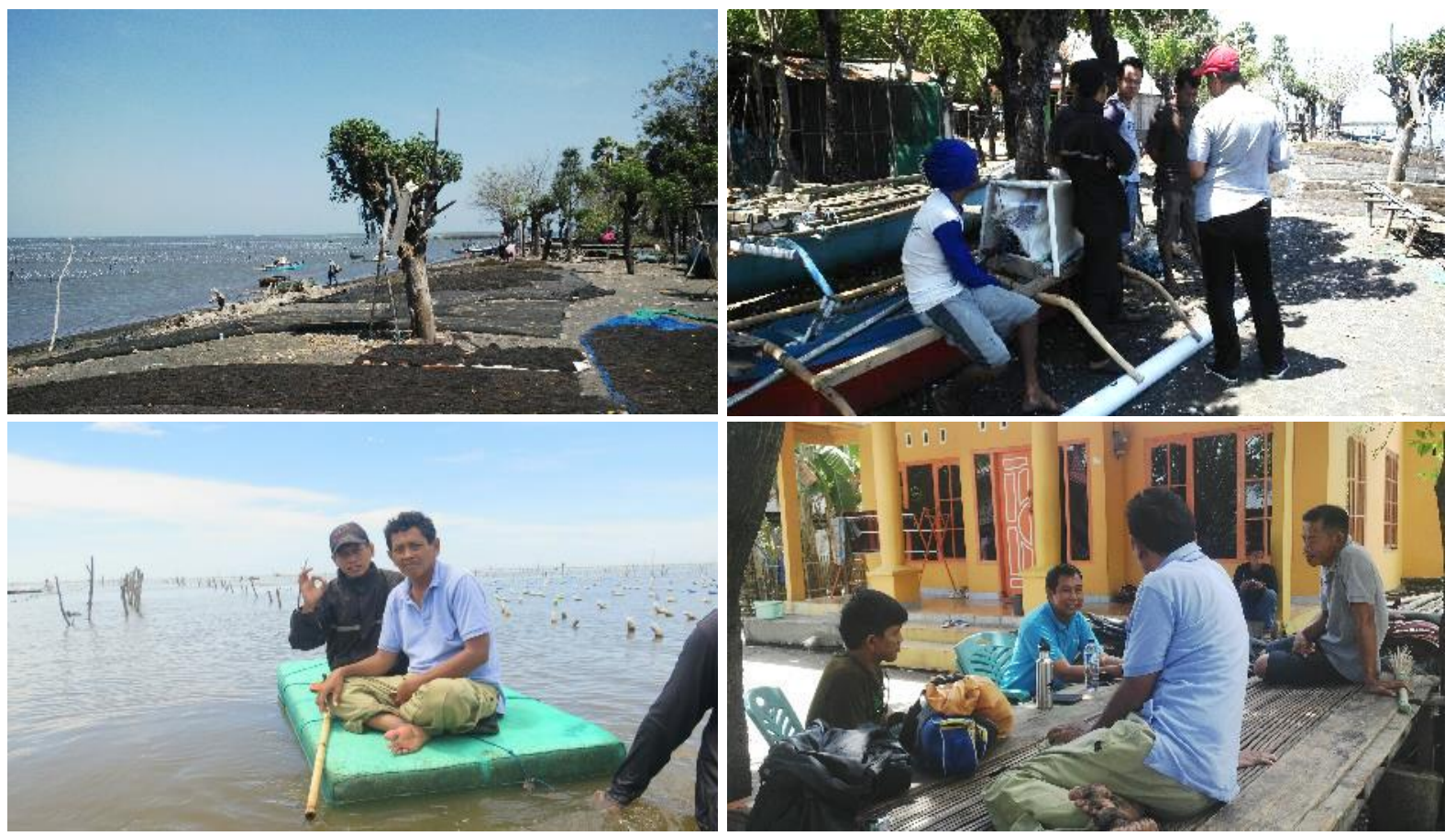

Gambar 4. Observasi dan Wawancara dengan Anggota Komunitas Dampingan

\section{Tahap Perancangan dan Perakitan Teknologi}


Tahap perancangan dan perakitan teknologi dilakukan melalui penyuluhan nonteknis dan pendampingan teknis. Penyuluhan non-teknis dilakukan dengan menyampaikan pengetahuan teoritis tentang konsep budidaya rumput laut metode vertikal. Pendampingan teknis dilakukan dengan mendemonstrasikan pembuatan konstruksi. Konstruksi ini dibuat dengan menggunakan alat dan bahan, antara lain gergaji, bor, pipa PVC 1", pipa sambungan L dan T, tali PE10, tali PE6, lem pipa, dan jerigen, dan paku. Konstruksi dibuat berbentuk persegipanjang ukuran 2x1 meter. Untuk membuat 1 konstruksi wadah dibutuhkan 7 buah pipa berukuran 1 meter, 4 buah sambungan L, dan 2 buah sambungan T. Sambungan L yang akan berada di masingmasing sudut dilubangi sebagai tempat untuk memasukkan tali penghubung antar kolom. Pipa yang melintang masing-masing dilubangi sebanyak 4 lubang untuk memasukkan tali bentangan. Selanjutnya wadah dikonstruksi berbentuk persegipanjang dengan menyambungkan pipa melalui pipa. Pada setiap konstruksi dibuat 4 tali bentangan dengan jarak antar bentang $25 \mathrm{~cm}$. 1 unit konstruksi tersusun 4 kolom sebagai media rumput laut. Khusus untuk kolom paling bawah yang dekat dasar perairan, pipa diisi dengan cor semen yang maksudkan sebagai pemberat sehingga konstruksi lebih stabil. Kolom paling atas dilengkapi dengan pelampung berupa jerigen. Konstruksi budidaya rumput laut metode vertikal disajikan pada Gambar 5.
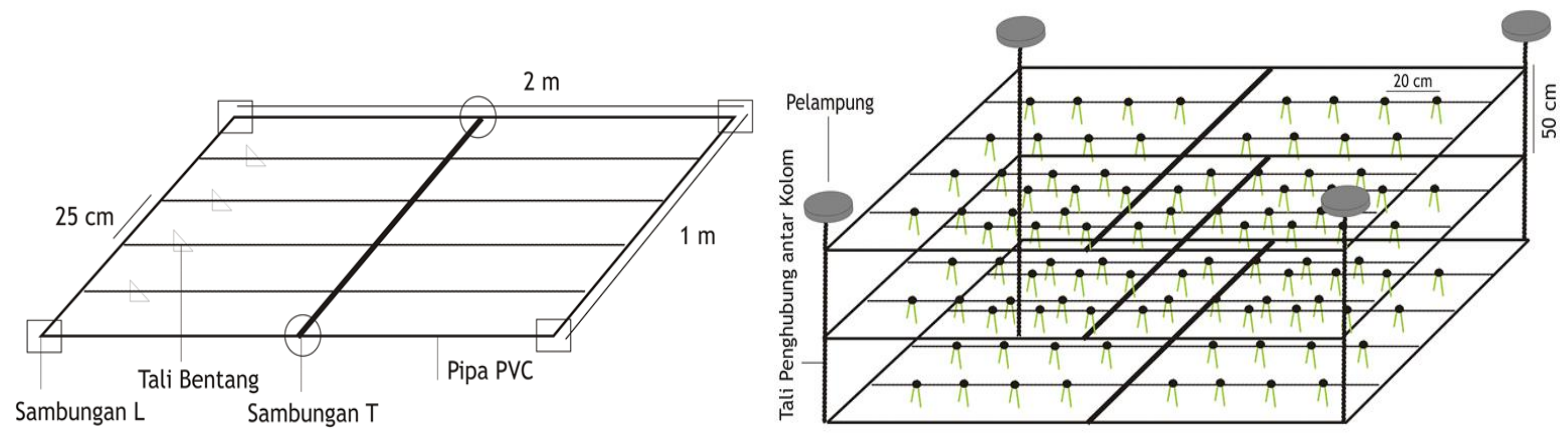

Gambar 5. Konstruksi Wadah Rumput Laut Metode Vertikal21

Budidaya rumput laut metode vertikal merupakan teknologi baru bagi komunitas dampingan sehingga sangat antusias dalam mengikuti penyuluhan non-teknis dan pendampingan teknis. Hal ini dapat dlihat dari keterlibatan anggota komunitas dampingan dalam persiapan dan pembuatan konstruksi serta keaktifan berdiskusi pada saat penyuluhan dan pendampingan teknis. Dokumentasi kegiatan pada tahap perancangan dan perakitan teknologi disajikan pada Gambar 6.

21 Nursidi, Mauli, and Heriansah, "Development of Seaweed Kappaphycus Alvarezii Cultivation through Vertical Method in the Water of Small Islands in South Sulawesi, Indonesia." 


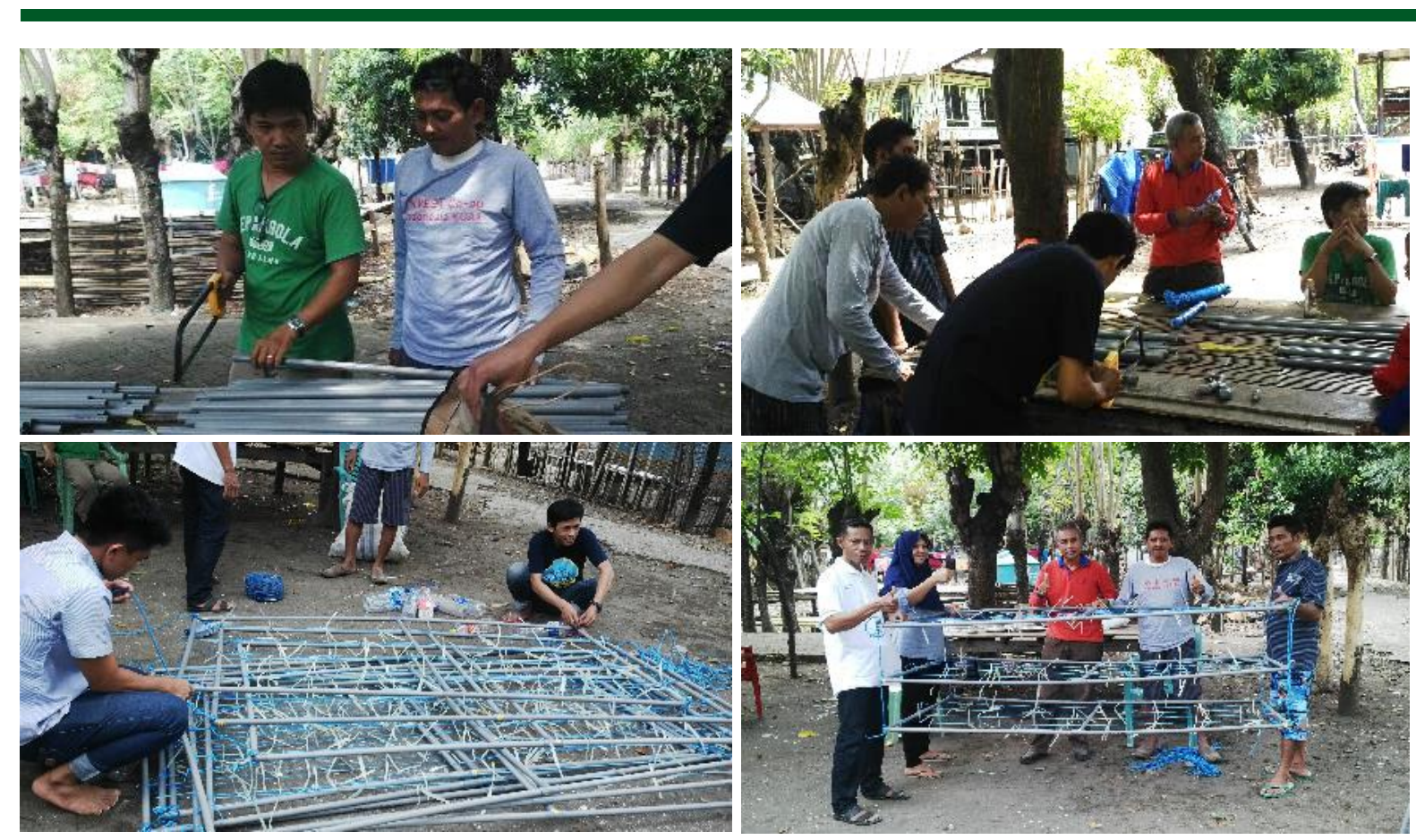

Gambar 6. Konstruksi Wadah Rumput Laut Metode Vertikal

\section{Tahap Implementasi Teknologi}

Tahap implementasi teknologi dilakukan melalui demonstrasi plot, meliputi demonstrasi pengikatan bibit dan penempatan wadah di lokasi budidaya. Bibit rumput laut seberat \pm 50 gr diikat sebanyak 7 titik ikat per bentang pada 4 tali bentang dengan menggunakan tali PE. Pengikatan rumput laut bukan merupakan hal baru bagi komunitas dampingan karena sudah terbiasa mengikat rumput laut pada metode horisontal yang diaplikasikan selama ini. Bibit rumput laut $G$. changii diperoleh dari unit pembibitan yang berada di Desa Ujung Baji. Setelah pengikatan bibit, 3 unit konstruksi ditempatkan di lokasi budidaya yang relatif berdekatan dengan area budidaya milik salah satu komunitas dampingan yang menggunakan metode horisontal. Selanjutnya dilakukan pendampingan pemeliharaan selama 40 hari dan pengontrolan setiap 10 hari untuk memantau pertumbuhan rumput laut serta mengontrol tali bentang dan tali ikat konstruksi. Dokumentasi kegiatan pada tahap implementasi teknologi disajikan pada Gambar 7.
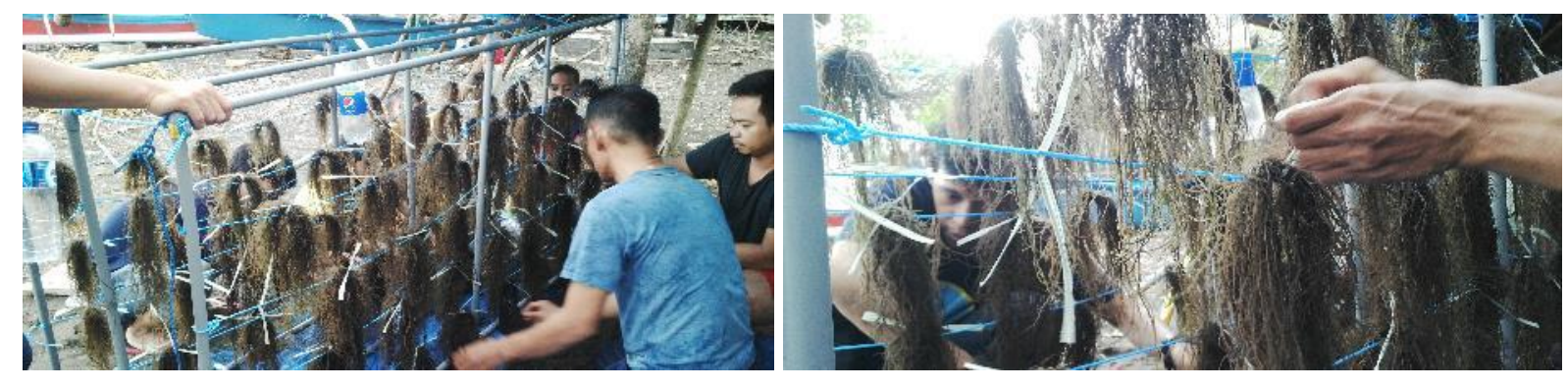

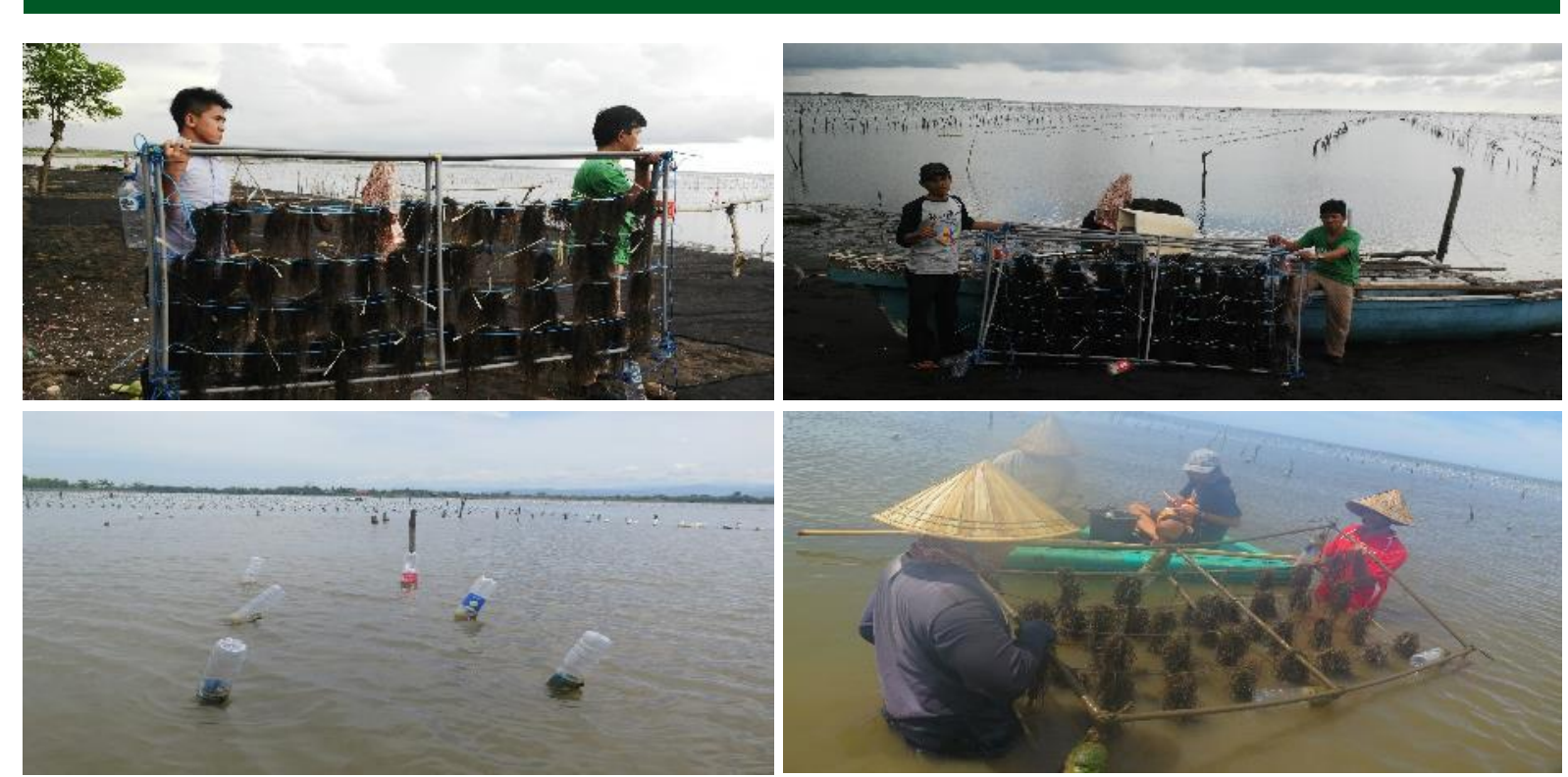

Gambar 7. Pengikatan Bibit serta Penempatan dan Pengontrolan Konstruksi Wadah

\section{Tahap Evaluasi}

Tahap evaluasi dilakukan pada akhir diseminasi dengan membandingkan pengetahuan dan keterampilan sebelum dengan sesudah diseminasi dilaksanakan. Hasil evaluasi dengan menggunakan instrumen pre-test dan post-test serta pengamatan unjuk kerja 11 anggota komunitas dampingan disajikan pada Gambar 8.

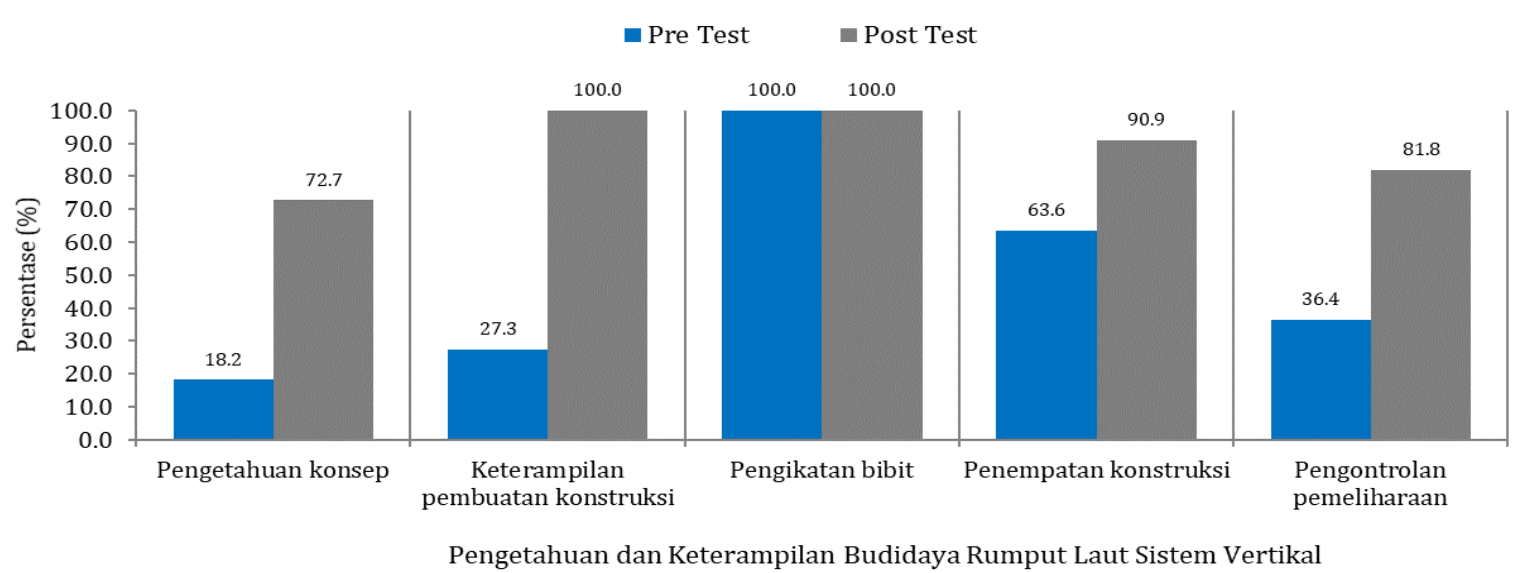

Gambar 8. Grafik Peningkatan Pengetahuan dan Keterampilan Komunitas Dampingan

Gambar 8 menunjukkan peningkatan pengetahuan dan keterampilan komunitas dampingan mitra mengenai konsep budidaya rumput laut metode vertikal, pembuatan konstruksi, penempatan konstruksi, dan pengontrolan saat pemeliharaan. Pengetahuan dan keterampilan terkait konsep dan pembuatan konstruksi meningkat masing-masing 54,4\% dan 72.7\%. Pengikatan rumput laut bukan merupakan hal baru sehingga komunitas dampingan sudah mengetahui cara pengikatan bibit yang baik dan benar. Pengetahuan dan keterampilan terkait penempatan konstruksi dan pengontrolan selama 
pemeliharaan meningkat masing-masing 27,3\% dan 45,5\%.

Metode vertikal pada konteks peningkatan produksi juga terjadi peningkatan dibandingkan dengan metode horisontal. Pada metode vertikal, rata-rata bobot akhir rumput laut per titik ikat pada kolom pertama 353,2 gr, kolom kedua 371,7 gr, dan kolom ketiga 294,5 gr. Jika dihitung secara total, produksi pada kolom pertama sebanyak 2,47 $\mathrm{kg}$, kolom kedua 2,62 kg, dan kolom ketiga 2,06 kg. Jika dikonversi sesuai dengan panjang bentangan yang digunakan komunitas dampingan $(25 \mathrm{~m}$ per bentang sebanyak 50 bentang) , maka pada panjang dan jumlah bentangan yang sama, metode vertikal dapat menghasilkan 3,6 ton yang terdiri dari 1,2 ton pada kolom pertama, 1,3 ton pada kolom kedua, dan 1,0 ton pada kolom ketiga. Jumlah ini meningkat dua sampai tiga kali dibandingkan dengan metode horisontal yang hanya menghasilkan produksi 1-2 ton.

\section{Diskusi}

Pelaksanaan diseminasi memberikan dampak positif terhadap peningkatan pengetahuan dan keterampilan komunitas dampingan dalam menerapkan teknologi budidaya rumput laut metode vertikal. Secara umum komunitas dampingan menganggap bahwa diseminasi ini secara teknis mudah diadopsi dan mereka termotivasi untuk mengembangkan dan memodifikasi konstruksi sesuai dengan sumberdaya yang dimiliki. Hal ini tidak terlepas dari jenis teknologi dan metode desiminasi yang digunakan sesuai dengan kebutuhannya. Teknologi budidaya rumput laut telah berkembang pesat pada beberapa dekade terakhir, tetapi tidak semua teknologi tersebut telah diadopsi dengan mudah oleh pembudidaya ${ }^{22}$. Beberapa faktor yang mempengaruhi proses adopsi teknologi budidaya, antara lain metode transfer, karakteristik teknologi, faktor ekonomi, dan karakteristik usaha ${ }^{23}$. Faktor-faktor yang saling terkait ini dinilai sangat berperan dalam menunjang keberhasilan diseminasi teknologi budidaya metode vertikal bagi komunitas pembudidaya rumput laut di Pesisir Desa Ujung Baji Kabupaten Takalar.

Metode transfer teknologi pada kegiatan diseminasi ini menggunakan metode Community Development. Tiga prinsip utama program pengembangan masyarakat, yaitu: (1) berbasis masyarakat, (2) berbasis sumberdaya setempat, dan (3) berkelanjutan ${ }^{24}$. Ketiga prinsip ini diintegrasikan pada kegiatan diseminasi teknologi kepada masyarakat dampingan. Anggota Kelompok Pembudidaya Hati Mulia sebagai komunitas dampingan dijadikan sebagai subyek atau pelaku utama, baik dalam perencanaan maupun pelaksanaan program. Teknologi yang didiseminasikan selaras dengan potensi sumberdaya alam dan pembudidaya yang ada di wilayah kegiatan. Teknologi budidaya

22 Ganesh Kumar, Carole Engle, and Craig Tucker, “Factors Driving Aquaculture Technology Adoption," Journal of the World Aquaculture Society 49, no. 3 (2018): 447-476.

23 Ibid.

${ }^{24}$ Arsawan, Kariati, and Sukarta, "Pemberdayaan Berbasis Comunnity Development: Studi Ekploratorif Di Kawasan Wisata Sangeh." 
metode vertikal merupakan hal baru bagi komunitas dampingan sehingga dapat menjadi penggerak awal atau pengungkit penyebaran dan keberlanjutan teknologi bagi masyarakat sekitar. Proses komunikasi dengan masyarakat dampingan yang dibangun mulai dari awal sampai akhir kegiatan pada proses diseminasi yang dilakukan turut berperan dalam mengefektifkan penerapan prinsip pengembangan masyarakat. Relasi antara pencipta atau pembawa dengan pengguna teknologi merupakan salah satu faktor yang sangat penting dalam menunjang keberhasilan transfer teknologi 25 .

Karakteristik dari sebuah teknologi memainkan peran penting dalam mempengaruhi seorang petani/pembudidaya dalam mengambil keputusan untuk mengadopsi teknologi baru ${ }^{26}$. Karakteristik teknologi budidaya rumput laut metode vertikal ini sangat relevan dan dibutuhkan untuk meningkatkan produksi. Budidaya metode vertikal yang sering pula disebut dengan metode vertikultur merupakan metode budidaya rumput laut dengan cara mengikatkan bibit rumput laut dengan posisi vertikal pada tali-tali yang disusun berjajar sehingga nutrien yang berada di kolom perairan dapat dioptimalkan pemanfaatannya 27,28 . Penetrasi cahaya matahari sebagai syarat tumbuh rumput laut dapat diperoleh tidakhanya dari satu sisi permukaan perairan saja, melainkan dari berbagai sisi dan sudut datangnya cahaya matahari. Disisi lain, kandungan zat hara perairan masih terdapat pada kolom air sampai pada batas penetrasi cahaya matahari ${ }^{29}$. Kedua hal ini merupakan pertimbangan utama dalam menerapkan metode budidaya verikal melalui optimalisasi pemanfaatan kolom perairan untuk meningkatkan produktivitas lahan. Dengan demikian, aplikasi metode vertikal dapat mengintensifkan pemanfaatan lahan sehingga dapat meningkatkan produksi rumput laut ${ }^{30}$. Pada konteks tersebut, budidaya metode vertikal dapat diterapkan sebagai alternatif metode di wilayah yang sempit untuk meningkatkan produksi rumput laut secara optimal tanpa mempengaruhi kualitas rumput laut ${ }^{31}$.

Faktor ekonomi terutama keuntungan yang diperoleh juga mempengaruhi adopsi baru teknologi. Harapan dari keuntungan yang lebih besar diidentifikasi sebagai alasan utama penerimaan teknologi oleh masyarakat perikanan ${ }^{32}$. Hasil produksi dan hitungan matematis telah memberikan keyakinan kepada komunitas dampingan bahwa teknologi

25 Sari et al., "Critical Role of Intermediaries on Technology Transfer: Case Study of BIOTROP and Center for Mariculture Development of Lampung," Jurnal Manajemen Teknologi 16, no. 1 (2017): 33-45.

${ }^{26}$ Kumar, Engle, and Tucker, "Factors Driving Aquaculture Technology Adoption."

27 Nursidi, Mauli, and Heriansah, "Development of Seaweed Kappaphycus Alvarezii Cultivation through Vertical Method in the Water of Small Islands in South Sulawesi, Indonesia."

${ }^{28}$ Pong-Masak and Sarira, "Effect of Depth on the Growth and Carrageenan Content of Seaweed Kappaphycus Alvarezii Cultivated Using Verticulture Method."

${ }^{29}$ Lestari Lakhsmi Widowati et al., "Efisensi Produksi Rumput Laut E. Cotonii Dengan Metode Budidaya Longline Vertikan Sebagai Alternatif Pemanfaatan Kolom Air."

30 Pong-Masak and Sarira, "Effect of Depth on the Growth and Carrageenan Content of Seaweed Kappaphycus Alvarezii Cultivated Using Verticulture Method."

31 Ibid.

${ }^{32}$ Kumar, Engle, and Tucker, “Factors Driving Aquaculture Technology Adoption.” 
budidaya rumput laut metode vertikal dapat meningkatkan produksi dan produktivitas usaha karena pada satuan luas lahan yang sama diperoleh hasil produksi yang lebih banyak. Produksi rumput laut pada budidaya metode vertikal meningkat dua sampai tiga kali dibandingkan dengan metode horisontal.

Karakteristik usaha pada beberapa studi menunjukkan bahwa sifat kepemilikan lahan memainkan peran penting dalam keputusan adopsi ${ }^{33}$. Komunitas dampingan pada kegiatan diseminasi ini umumnya memiliki lahan budidaya rumput laut sendiri yang telah dijalankan sejak lama. Lahan dengan status milik sendiri dapat mempengaruhi keputusan pembudidaya untuk berinvestasi dalam menerapkan teknologi yang dapat meningkatkan produksi dan produktivitas lahan.

\section{Simpulan}

Hasil kegiatan diseminasi teknologi di Desa Ujung Baji Kabupaten Takalar pada aspek sosial dapat meningkatkan pengetahuan dan keterampilan Kelompok Pembudidaya Hati Mulia dalam membudidayakan rumput laut G. changii dengan metode vertikal. Pada aspek ekonomi metode budidaya vertikal dapati meningkatkan produksi dan pendapatan pembudidaya. Pendapatan yang meningkat dapat berdampak terhadap peningkatan kesejahteraan pembudidaya. Direkomendasikan kepada pembudidaya untuk menerapkan teknologi budidaya metode vertikal pada skala yang lebih besar agar produktivitas lahan semakin meningkat.

\section{Pengakuan}

Ucapan terima kasih yang sebesar-besarnya disampaikan kepada: (1) Kementerian Riset, Teknologi dan Pendidikan Tinggi Republik Indonesia atas Program Teknologi yang Didiseminasikan ke Masyarakat (DPTM) yang sangat bermanfaat dalam menghilirisasi teknologi ke masyarakat, (2) Ketua dan anggota Kelompok Pembudidaya Rumput Laut Hati Mulia beserta masyarakat Desa Ujung Baji Kabupaten Takalar atas kerjasama dan partisipasi aktifnya, dan (3) para mahasiswa Politeknik Pertanian Negeri Pangkep dan Sekolah Tinggi Teknologi Kelautan (berubah bentuk menjadi Institut Teknologi dan Bisnis Maritim Balik Diwa Makassar serta mahasiswa praktek dari Sekolah Tinggi Perikanan (STP) Jakarta yang telah ikut membantu pelaksanaan program diseminasi ini.

\section{Referensi}

Arbit, N. I.S., S. B.A. Omar, E. Soekendarsi, I. Yasir, J. Tresnati, Mutmainnah, and A. Tuwo.

33 Ibid. 
"Morphological and Genetic Analysis of Gracilaria Sp. Cultured in Ponds and Coastal Waters." IOP Conference Series: Earth and Environmental Science 370, no. 1 (2019).

Arsawan, I Wayan Edi, Ni Made Kariati, and I Wayan Sukarta. "Pemberdayaan Berbasis Comunnity Development: Studi Ekploratorif Di Kawasan Wisata Sangeh." Sosial dan Humaniora 6, no. 3 (2016): 238-248.

BPS. Kecamatan Sanrobone Dalam Angka 2020. Takalar, 2020. https://takalarkab.bps.go.id/publication/2020/09/28/b6fe3fe83c14387edfce3a3 4/kecamatan-sanrobone-dalam-angka-2020.html.

Chabib Musthofa, and Muhammad Andik Izzuddin. "Pengembangan Model Usaha Tanaman Hidroponik Melalui Pemanfaatan Teknologi Tepat Guna Berbasis Media Informasi Pada Komunitas UMKM Pertanian Perkotaan." Engagement: Jurnal Pengabdian Kepada Masyarakat 3, no. 1 (2019): 92-105.

Chan, Pei Teng, and Patricia Matanjun. "Chemical Composition and Physicochemical Properties of Tropical Red Seaweed, Gracilaria Changii." Food Chemistry 221 (2017): 302-310. http://dx.doi.org/10.1016/j.foodchem.2016.10.066.

Chan, Pei Teng, Patricia Matanjun, Suhaimi Md Yasir, and Tek Song Tan. "Antioxidant and Hypolipidaemic Properties of Red Seaweed, Gracilaria Changii." Journal of Applied Phycology 26, no. 2 (2014): 987-997.

Hendri, Muhammad, Rozirwan Rozirwan, and Rezi Apri. "Optimization of Cultivated Seaweed Land Gracilaria Sp Using Vertikultur System." International Journal of Marine Science 7, no. 43 (2017): 411-422.

Jong, Lin Wei, Vun Yee Thien, Yoong Soon Yong, Kenneth Francis Rodrigues, and Wilson Thau Lym Yong. "Micropropagation and Protein Profile Analysis by SDS-PAGE of Gracilaria Changii (Rhodophyta, Solieriaceae)." Aquaculture Reports 1 (2015): 1014. http://dx.doi.org/10.1016/j.aqrep.2015.03.002.

Kumar, Ganesh, Carole Engle, and Craig Tucker. "Factors Driving Aquaculture Technology Adoption." Journal of the World Aquaculture Society 49, no. 3 (2018): 447-476.

Lee, Wei Kang, Yi Yi Lim, and Chai Ling Ho. "PH Affects Growth, Physiology and Agar Properties of Agarophyte Gracilaria Changii (Rhodophyta) under Low Light Intensity from Morib, Malaysia." Regional Studies in Marine Science 30 (2019): 100738. https://doi.org/10.1016/j.rsma.2019.100738.

Lestari Lakhsmi Widowati, Sri Rejeki, Tristiana Yuniarti, and Restiana Wisnu Ariyati. "Efisensi Produksi Rumput Laut E. Cotonii Dengan Metode Budidaya Longline Vertikan Sebagai Alternatif Pemanfaatan Kolom Air." Indonesian Journal of Fisheries Science and Technology (IJFST) 11, no. 1 (2015): 47-56.

Mulyono, Mugi, Sri Budiani Samsuharapan, Erni Marlina, Maria Goreti, Eny Kristiany, Effi Athfiyani Thaib, Amyda Suryati Panjaitan, et al. "Performa Budidaya Rumput Laut." 
Media Akuakultur 15, no. 2 (2020): 71-77.

Nursidi, Mauli, and Heriansah. "Development of Seaweed Kappaphycus Alvarezii Cultivation through Vertical Method in the Water of Small Islands in South Sulawesi, Indonesia." AACL Bioflux 10, no. 6 (2017): 1428-1435.

Pong-Masak, Petrus Rani, and Nelly Hidayanti Sarira. "Effect of Depth on the Growth and Carrageenan Content of Seaweed Kappaphycus Alvarezii Cultivated Using Verticulture Method." E3S Web of Conferences 147 (2020).

Sari, Karlina, Purnama Alamsyah, Anugerah Yuka Asmara, Kusnandar Kusnandar, and Sri Mulatsih. "Critical Role of Intermediaries on Technology Transfer: Case Study of BIOTROP and Center for Mariculture Development of Lampung." Jurnal Manajemen Teknologi 16, no. 1 (2017): 33-45.

“Administrasi-Takalar1." Last modified 2013. https://petatematikindo.files.wordpress.com/2013/01/administrasi-takalar1.jpg.

"Indonesia Lupakan Keajaiban Di Takalar Halaman All - Kompasiana." https://www.kompasiana.com/harrystbagindo/5b73f105c112fe45b70d2ce5/indo nesia-lupakan-keajaiban-di-takalar?page=all.

"Ujung Baji - Google Maps," https://www.google.com/maps/place/Ujung+Baji,+Sanrobone,+Takalar+Regency, + South+Sulawesi/. 